\title{
Research on the Popularity of Cosmetics and its Future in Vietnam Market
}

\author{
Nguyen Tan DANH \\ FPT University, Vietnam, E-mail: nguyentandanh0774@gmail.com \\ ${ }^{*}$ Corresponding Author
}

\begin{abstract}
Received: 14.11.2021
Accepted: 20.12.2021

Published: 01.02.2022

DOI: $10.47750 / \mathrm{QAS} / 23.186 .03$

Abstract

Cosmetics are gradually becoming an indispensable necessity in life. Grasping that, many cosmetic brands are gradually appearing and occupying a large market, besides the 4.0 era has created many opportunities as well as presented competition in the industry. Currently, $90 \%$ of Vietnamese cosmetic enterprises are distribution agents of foreign partners. The purpose of this study is to investigate the preference for imported cosmetics by consumers in the Vietnamese market and to clarify the position of the foreign cosmetics industry in our domestic market. From there, predicting the near future of the domestic cosmetics industry as well as the consumption trends of Vietnamese people. Wishing to bring a clearer view to the development as well as increase the competitiveness of the domestic cosmetics industry in Vietnam. The article was completed based on an online survey with the audience being consumers of all kinds of cosmetic products available on the Vietnamese market.
\end{abstract}

Keywords: consumer survey, cosmetic, market

\section{Introduction}

The era is more and more developed, that has gradually brought people different necessities compared to the old days. Not only eating and sleeping, but now there are other needs such as entertainment, beauty, learning, etc. Thanks to those needs, new markets have created huge profits in the economy. One of them, the cosmetic market is holding a large market share and is having a strong development trend. Grasping the needs and potential of the industry, many new brands appear, creating fierce competition. And now Vietnam has a growing number of consumers, becoming a potential market, but currently $90 \%$ of cosmetic businesses in Vietnam are distribution agents for foreign partners. One of the reasons for this imbalance is because of the preference for imported products by Vietnamese consumers, besides that, it is also because the domestic cosmetics company in the country has not found a foothold yet for yourself. Therefore, this study will find out the reasons that consumers choose products and based on that to make predictions about the market in the near future to help domestic firms increase their competitiveness to capture this big market.

\section{Research history}

According to Nguyen \& Homolka (2021), consumers are affected by factors such as (online shopping experience; Seller's services; External influences; Security / Privacy) outside Also affected by the seller's services and other incentives. Authors Nguyen \& Homolka (2021) gave reasons that have the most obvious impact on buyers. In addition, Choi (2014) also mentioned that the Vietnamese market was mainly influenced by the Korean wave and 西山茂 (2014) pointed out that the number of Japanese companies expanding into Vietnam is increasing. Because of the interference of countries, product products become diverse, especially from countries with great influence, so Luong et al (2017) to attract consumers, marketers has come to appreciate, recognize and utilize brands and products as a useful marketing tool. According to Ngoc (2014), brand loyalty including perceived quality and country of origin is assessed as having a positive and significant influence on the overall brand value of consumers. Besides, Sy \& Mai (2015) added that the perception of external stakeholders about the company is associated with the remaining two concepts: image and reputation. The characteristics of the business and organization that the organization wants to convey content and information to external objects to understand, the image and reputation are factors for interested objects to evaluate. From the factors that create customer preference for products, brands must know how to take advantage of those factors. Pham \& Do (2016) pointed out other influencing factors such as external appearance, marketing style and service quality in shaping customer satisfaction. And Thao (2020) mentions that raising awareness about product packaging will increase perceived value and promote consumer behavior of items and the combination of marketing activities contributes to brand building. in the hearts of customers when buying cosmetics.

In addition, Nguyen (2020) gives an opinion about branding, in the modern world of communication, with the convenience of online channels via the internet, now their personal sharing have a more significant impact on those around them as many online users can easily and quickly read such feedback to be able to make purchasing decisions. Besides, according to Lee et al. (2017), consumers mainly focus on ingredients when buying, so when they want to enter the market, newly launched brands or unknown brands need to focus more on excellence in ingredients and special functions of the product to attract consumers. 


\section{GENERAL MANAGEMENT}

\section{Research content}

Due to the increasingly diverse needs of users along with the development of technology, the cosmetic market has a high growth trend, and in Vietnam with a young population, it is always actively catching up with the trends of making cosmetics beautiful in the world.

First, there is the explosion of the middle class in Asia in general and Vietnam in particular. This class is increasingly spending on beauty care. According to statistics, currently a middle-class woman in Vietnam spends an average of 450,000 - 500,000 VND/month on makeup and skin care products.

Asia Plus Company conducted a survey on the use of makeup cosmetics of nearly 500 women aged 16 - 39 across the country. The results show that in the past 3 years, the number of women who wear makeup has increased from $76 \%$ to $86 \%$, and at the same time, the number of people who wear makeup daily or regularly also increase from $35 \%$ to $39 \%$, because of the increased consumption has fueled the industry's dizzying growth. According to Yano Research Institute (Japan), in Southeast Asia, Vietnam is one of the fastest growing cosmetic markets. In 2018, this market reached a value of 2.35 billion USD. It is expected that in the next 10 years, the growth rate of Vietnam's skin care and makeup cosmetics market will be about $15-20 \% /$ year.

According to data provided by the Ho Chi Minh City Cosmetics Association, Korea accounts for the largest proportion of sales in the Vietnamese market with $30 \%$ followed by the EU with $23 \%$, Japan (17\%), Thailand (13\%) and the US $(10 \%)$, the rest accounted for $7 \%$ of the total market (Le et al., 2020).

According to the survey, different age groups also tend to use different cosmetics. More than half of people aged 23 and over, they usually wear makeup when going to work/school, going out or attending parties. Besides, people in this age group use more skin care products and in which $60 \%$ of them use skin care cosmetics daily.

People who don't wear makeup are often young people with the most common reason because they don't know how or don't have time for it.

Although they are of different ages, when using cosmetics, the common point is that lipstick and facial cleanser (including makeup remover) are the most used products in the group of makeup and skin care products.

And according to the survey, traditional shopping in commercial stores still tops the table for consumers. In addition, $73 \%$ of the survey respondents also used to shop online, the online channel is becoming a competitive battleground today.
And consumers continue to increase their spending on cosmetics by $10 \%$ over time.

And according to statistics, the care product market, the statistics of the current market segment are distributed as follows:

Body care: $7 \%$ market value. Facials: $92 \%$ of market value including: acne, masks, cleansers, lotions: highest in this segment with $46 \%$ of market value), lip balm, anti-aging and last same with Hand Care: $1 \%$ of market price

At the same time, survey the Vietnamese market, which is currently in the hands of big foreign brands. There are about 430 domestic cosmetic companies in total, but the market share is mainly in the hands of a few foreign brands such as L'Oréal, Shiseido, Clarins, etc. There are about 100 cosmetic brands in Vietnam, but $90 \%$ of them are. is imported. And the top big guys in order are:

$\square$ Unilever: leading about $12 \%$ of the total market, famous brand: Pond's

$\square$ Beiersdorf Vietnam: Nivea

$\square$ LG Vina Cosmetics: Ohui (high-end cosmetic line), The

Face Shop (popular cosmetic line)

$\square$ Shiseido Cosmetics Vietnam: Shiseido

$\square$ L'Oréal Vietnam Co Ltd: L'Oréal

$\square$ AmorePacific Vietnam: Laneige, Innisfree

From the above data, it can be seen that consumers are very fond of famous international brands. And almost all use foreign cosmetic products.

\section{Methods scope and research object}

The article is based on surveys for consumers of cosmetic products of various ages across Vietnam. The data is collected by survey and comparison method to provide data as well as a clear view of the current domestic cosmetic market to suggest ways to help promote the domestic cosmetics industry.

\section{Research Results and Discussion}

Along with the development of the times, the chemical industry has brought products that meet the material and spiritual needs of mankind according to Lee et al (2017). Besides the cosmetic industry occupies a large position in the economy and is on the rise, cosmetics seem to be an indispensable commodity for each individual, which is clearly shown in the following table.

\begin{tabular}{|l|l|l|l|l|l|l|l|l|}
\hline Frequency of using cosmetics & 1 & 2 & 3 & 4 & 5 & $\begin{array}{l}\text { Total } \\
\text { reply }\end{array}$ & $\begin{array}{l}\text { total } \\
\text { point }\end{array}$ & $\begin{array}{l}\text { Level } \\
\text { medium }\end{array}$ \\
\hline $\begin{array}{l}\text { Frequency of using care products } \\
\text { skin care }\end{array}$ & 2 & 5 & 4 & 17 & 1 & 29 & 97 & 0,62 \\
\hline $\begin{array}{l}\text { Frequency of using the product page } \\
\text { point }\end{array}$ & 6 & 10 & 9 & 4 & 0 & 29 & 60 & 0,38 \\
\hline & & & & & & & 159 & 1.00 \\
\hline
\end{tabular}

\section{Table 1: Frequency of using cosmetics}

In (Table 1), two questions are posed for the purpose of understanding the trend of using cosmetics in Vietnam. The data shows that Vietnamese consumers tend to use skin care products $(0.62 \%)$ higher than using makeup products $(0.38 \%)$. So it can be concluded that Vietnam's market is studying more about cosmetic care.
In addition, according to (Graph 1), it can be clearly seen that the number of people who do not use at all has a huge difference with the number of people who use $6.9 \%$ and $93.1 \%$, accounting for more than $90 \%$ and most of them do not use it. All female customers. The market for cosmetics and beauty products has grown significantly as consumers have increased their 


\section{GENERAL MANAGEMENT}

awareness of the importance and care of their appearance leading to the choice of personal care products according to Khraim, 2011). Therefore, it can be realized that this is a market that deserves more attention from Vietnamese businesses and should promote participation in the segment of care products

\begin{tabular}{|l|l|l|l|l|l|l|l|l|}
\hline Satisfaction level & 1 & 2 & 3 & 4 & 5 & $\begin{array}{l}\text { Total } \\
\text { reply }\end{array}$ & $\begin{array}{l}\text { total } \\
\text { point }\end{array}$ & $\begin{array}{l}\text { Level } \\
\text { medium }\end{array}$ \\
\hline $\begin{array}{l}\text { Cosmetic quality } \\
\text { foreign brand }\end{array}$ & 0 & 1 & 4 & 18 & 6 & 29 & 116 & 0.57 \\
\hline $\begin{array}{l}\text { Cosmetic quality } \\
\text { Vietnamese brand }\end{array}$ & 1 & 3 & 19 & 6 & 0 & 29 & 88 & 0.47 \\
\hline & & & & & & & 204 & 1.00 \\
\hline
\end{tabular}

Table 2: Level of satisfaction with cosmetics.

According to (Table 2), with the purpose of giving consumers' views on domestic and foreign products, the data shows that Vietnamese consumers are satisfied with foreign products, because of many reasons but Vietnamese products are lagging behind, and there is no way to compete with foreign firms. Businesses need to find out the reasons that motivate and create consumers' purchasing decisions as well as their buying habits as mentioned by Luong et al (2017).

Quality ingredients are a natural factor when consumers

Next is price ranked second in the survey, the reason is that the number of cosmetic users in Vietnam are young customers who do not have too high income, they are not willing to pay a much to use cosmetics. Therefore, they do not need to promote the brand or the packaging, which is an advantage for Vietnamese businesses. Because according to a survey, $90 \%$ of consumers say yes to try products that are not well-known but highly appreciated brands.

In the 4.0 era with the development of the internet, traditional shopping is still the first choice of Vietnamese consumers, as chart 5 shows, the traditional method $(20,3)$ is dominated by the shopping method online (37.6\%) outperformed $17 \%$. The Internet has now become a major consumer market for the cosmetics industry.

According to Khraim (2011) brand loyalty is very important especially for an organization to ensure that consumers keep the product in their mind and prevent them from switching to other brands. If we can satisfy customers, this is the most important goal that businesses need to remember.

\section{Some proposed solutions}

Therefore, in addition to improving product quality, it is necessary to improve to compete, at the same time, it is also necessary to actively create diversity for products, creating more choices for customers.

In addition, manufacturers need to take measures to adjust prices to suit their needs. Because the customers are students, cosmetic dealers should aim for products that are not too expensive or too low mentioned by (Lee et al., 2020).

If businesses in Vietnam take advantage of domestic human resources and materials, they will be able to offer products that are not taxed too high and have a good price suitable for Vietnamese people to compete.

And with brands, now due to the Korean wave, brands have used marketing methods such as using celebrities to influence shopping behavior, as well as many other marketing factors to build brands. According to the survey, most consumers have switched to online buying, promoting more marketing on social platforms will bring more benefits, and at the same time must be careful to protect the brand's image. Wrong way marketing makes customers lose sympathy. Besides, as mentioned, the choose products. In the era of consumer development, it is easy for consumers to look up to grasp and learn about ingredients to assess the suitability of their body, to grasp that foreign brands are constantly offering new products. Products with a clear ingredient list, always innovate to attract users.

It can be seen that users always appreciate the variety of foreign cosmetics, many items with many uses and purposes, this gives customers a new feeling of what they do. that Vietnamese businesses have not yet met for consumers.

brand is not a high choice for young customers, this is an advantage.

Finally, the packaging factor, which is not an overestimated factor, but is still one of the factors that consumers choose to buy, the research results of Thao (2014) the more complete product packaging is enough information, especially the more convenient, the more positive impact on intention to continue to consume. And visual appeal will also moderate the impact on consumers' perceived social value.

The Vietnamese market is developing very strongly, being an object that foreign brands are constantly targeting, so to compete in this market requires grasping the psychological needs of customers, not Stop learning from famous brands, and continuously create unique products that help attract customers.

\section{Conclusion}

This research paper aims to give an overview of Vietnam's cosmetic market at the moment, as well as point out the factors that make consumers prefer imported products, thereby helping cosmetic businesses products in Vietnam have the right mindset to compete in this market. Through the research, it has been shown that imported products are occupying a great position by bringing satisfaction to customers through quality, marketing methods, variety of products and cosmetics in Vietnam that want to compete, then quality and price are the two points that can bring the most optimal, next is always to ensure the brand image and reasonable marketing method. In addition, the study also showed that Vietnamese women tend to use skin care products more than cosmetics and take advantage of online shopping channels as a form of promoting product consumption. Besides, packaging is also an important factor, the face of the product, the point that brands need to pay more attention to.

Vietnam is a potential market where domestic enterprises should step up their competition. In the near future, the market will become larger and larger, businesses must pay attention to exploit, avoid being pushed out of this market. 


\section{GENERAL MANAGEMENT}

\section{Limitations}

The article has some limitations due to the number of survey participants in large cities in Vietnam, so an exact number cannot be given. On that side, the market is also affected by other factors that should be updated from time to time. At the same time, it is necessary to update more diverse user documents to give insight into the market as well as on how to

\section{References}

[1] Nguyen, T. T. N., \& Homolka, L. (2021). Marital Status and Satisfaction of Online Shoppers in the Beauty and Cosmetic Sector in Vietnam. The Journal of Asian Finance, Economics, and Business, 8(2), 1005-1015.

[2] Luong, D. B., Vo, T. H. G., \& Le, K. N. (2017). The impacts of country of origin, price, and brand on consumer behavior toward cosmetics products: A review of Vietnam. International Journal of Research Studies in Management, 6(2). doi:10.5861/ijrsm.2017.2001

[3] Sỹ, N. T., \& Mai, N. T. (2015). Ảnh hưởng của quảng cáo đến hình ảnh và danh tiếng thương hiệu trường Đại học Ngoại thương. kinh tế và quản trị kinh doanh, 10(3), 75-84.

[4] Ngoc, C. T. (2014). Understanding the relationship between country of origin image and brand equity-case of cosmetic brands in Ho Chi Minh City. International Proceedings of Economics Development and Research, 78, 12.

[5] Thảo, H. T. P. (2020). Tác động của bao bì sản phẩm đến giá trị cảm nhận và ý định tiếp tục tiêu dùng đặc sản địa phương. Tạp chí Nghiên cứu Kinh tế và Kinh doanh Châu Á, 29(4), 3047.

[6] Lee, J. H., \& Yoh, E. (2017). What are Considered When Building Purchase Intention of Unfamiliar-Branded Cosmetics?. Fashion, Industry and Education, 15(2), 25-35.

[7] Pham, L. T., \& Do, B. N. (2016). The Determinants of Customer Satisfaction When Purchasing In-store Cosmetics in Vietnam. VNU Journal of Science: Economics and Business, 32(5E). promote the domestic cosmetics industry.

\section{Acknowledgement}

The article was completed under the supervision of teacher Huynh Tan Hoi, as well as the contributions of survey participants and individuals and groups who supported during the completion of the research paper.

[8] Choi, H., \& Lee, I. (2014). Fashion market analysis and design development for expansion to Southeast Asian market of Korean wave fashion-Focused on Vietnam, Ho Chi Minh City. Journal of the Korea Fashion and Costume Design Association, 16(2), 139-150.

[9] 西山茂. (2014). 日本の消費財メーカーのベトナム進出におけ る現状と課題. 早稲田国際経営研究, (45), 1-16.

[10] Nguyen, T. T. N. (2020). Developing and validating fiveconstruct model of customer satisfaction in beauty and cosmetic E-commerce. Heliyon, 6(9), e04887. doi:10.1016/j.heliyon.2020.e04887

[11] Salim Khraim, H. (2011). The Influence of Brand Loyalty on Cosmetics Buying Behavior of UAE Female Consumers. International Journal of Marketing Studies, 3(2). doi:10.5539/ijms.v3n2p123

[12] Hoi, H. T. (2020). Attractiveness of Online Marketing in the Age of Industry 4.0. Proceedings of the 2020 The 6th International Conference on E-Business and Applications. doi:10.1145/3387263.3387264.

[13] Le, T. A., Mai, N. Q. T., Vo, N. V., Tram, N. T. H., \& Nguyen, N. L. (2020). Factors affecting the choice of buying Korean cosmetics. Management Science Letters, 3097-3106. doi:10.5267/j.msl.2020.5.013 